\title{
The Ability Test of Fiber Degradation from Isolates Bacterial cellulolitic In The Rumen Buffalo (Bubalus bubalis)
}

\author{
Munir ${ }^{1,2}{ }^{*}$, Ambo Ako ${ }^{3}$, Syahriani Syahrir ${ }^{3}$ and Asmuddin Nasir ${ }^{3}$ \\ ${ }^{1}$ Department of Animal Husbandry, Faculty of Agriculture, Animal Husbandry and Fisheries Muhammadiyah University of Pare Pare, Jalan Jend.Ahmad Yani \\ km 6 Lapadde (0421) 22757, South Sulawesi, Indonesia \\ ${ }^{2}$ Doctoral Student at the University of Hasanuddin (UNHAS) Makassar, Indonesia \\ ${ }^{3}$ Department of Animal Husbandry, Faculty of Animal Science, University of Hasanuddin Makassar, Indonesia, Jalan Urip Sumoharjo (0411) 587217 Indonesia
}

Correspondence Author: Asmuddin Nasir, Department of Animal Husbandry, Faculty of Animal Science, University of Hasanuddin Makassar, Indonesia, Jalan Urip Sumoharjo (0411) 587217 Indonesia

Email: asmuddin_natsir@unhas.ac.id

Received date: 28 August 2019, Accepted date: 2 December 2019, Online date: 20 December 2019

Copyright: (C) 2019 Munir et al., This is an open-access article distributed under the terms of the Creative Commons Attribution License, which permits unrestricted use, distribution, and reproduction in any medium, provided the original author and source are credited.

\begin{abstract}
The ability of bacteria to degrade the fiber is a major factor in improving the quality of feed and simultaneously become a limiting factor in the provision of food, especially for ruminant feed. This study was designed as an exploratory study that analyzed descriptively to optimize performance on buffaloes bacteria that have the ability to digest fibrous feed better and accustomed to consuming fibrous feed materials such as rice straw. To analyze the ability of cellulolytic bacterial degradation to isolate bacteria taken from buffalo rumen fluid samples by growing the bacteria on four solid growth media that is aerobic, aerobic liquid, solid and anaerobic anaerobic liquid. Cellulolytic bacteria were isolated using a specific media Carboxy Methyl Cellulose (CMC) with a pour plate method were then incubated at $28^{\circ} \mathrm{C}$ for 48 hours. A total of four media growth with three replications. Data were analyzed using a completely randomized design (CRD) with SPSS software. The ability of cellulolytic bacterial degradation which is characterized by a clear zone around the colony's growing colony is then measured diameter, the diameter of clear zone and the resulting cellulolytic index. The results obtained indicate that there is a direct effect of treatment $(P<0.05)$ to the diameter of the colony with an $\mathrm{F} .20 .801 \mathrm{~mm}$, and with a clear zone $\mathrm{F} .30 .334 \mathrm{~mm}$ while the value of the index cellulolitic showed no differences between the isolates.
\end{abstract}

Keywords: Fiber Degradation, Isolate, Cellulolytic Bacteria, Rumen Buffalo.

\section{INTRODUCTION}

Potential fibrous straw as feed for ruminants potential especially in South Sulawesi, according to [1] that the rest of the harvest is positively correlated with the products generated in each district. The total production of 3,391,884 tons obtained consisted of $2,254,537$ tons of straw, husk, and bran as much as 814,816 tonnes 322,531 tonnes of the total output of 3,197,712 tons of rice, one feed material which has a high fiber and has a great potential of residual feed crop yields and available throughout the year is the rice straw, but is still constrained by the digestibility of rice straw is very low [2] so that the necessary efforts to improve the quality of processing. [3] Increase in value nutrition rice straw can be done by utilizing the services of buffalo rumen microbes in the process insulate rice straw. Cellulose contained in the rice straw is one fraction of coarse fibers of plants very difficult digested by enzymes pencertaan animals. Values kecemaan rice straw dry matter only reach $35-37 \%$ with a crude protein content of about $3-4 \%$, while for live ruminants require forage material with a minimum value of 50-55\% digestibility and crude protein content of about $8 \%$ [4]

Potential residual agricultural products are very large, such as rice straw requires more intensive processing to increase the value or quality by biological degradation processes fibers using cellulolytic bacteria that comes from buffaloes. [5] explains that handling biological waste is the handling of agricultural waste with the help of both aerobic and anaerobic microbes. Processing and preserving agricultural products with the rest of biological methods is highly dependent on the ability of microorganisms to harness chemical compounds as a source of carbon and energy with the aid of biological catalysts called enzymes. One genus of bacteria that live in the rumen and helps in digestion buffaloes include cellulolytic bacteria that can break down lignocellulose, lignohemiselulosa feed, and cellulose fibers. The bacteria can degrade cellulose because it produces an enzyme with different specifications of working together. The enzyme will hydrolyze bonds $(1,4)-\beta$-Dglukosa on cellulose [6]

Cellulolytic bacteria sources that can be used to degrade the fiber feed is derived from buffalo rumen bacteria potentially penghasilkan diverse as consume a wide variety of fibrous feed material. Cellulolytic bacteria's ability to produce enzymes capable hydrolyze cellulose to produce glucose that can be used for bacterial cell growth and division. This makes Livestock 
buffalo have the ability to digest fiber better than ruminants others, and support these animals survive in conditions of shortage of fodder in the dry season, especially in terms of digesting feed ingredients that have high fiber such as straw, which is the remainder agricultural product. [7] Reported that rumen bacterial isolates singly buffalo can digest dry matter grass and rice straw to successively $48.8 \%$ and $41.1 \%$. The addition of cellulolytic rumen microbial cultures buffalo at the level of $0.6 \%$ dry matter yield and rice straw organic materials by $48.67 \%$ and $55.10 \%$. [8]

[9-10] reported that the buffalo rumen fluid contains more cellulolytic microbes compared to other ruminants. In buffalo, rumen fluid was found seven colonies of microbes cellulolitic (group Ruminococcus sp.), While in cattle only four colonies. [11] research results showed that microbial rumen fluid buffalo cellulolytic activity turned out to have the highest compared with cellulolytic microbes derived from termites, elephant feces and cow rumen fluid. However, the amount and kinds of rumen microbial population depend on livestock feed consumed [12]. Isolation of bacteria from the rumen buffaloes very important for further examination in view of the number and types of bacteria in digesting feed ingredients vary [13] that the fibrous feed by microbial fermentation real crude fiber can increase the protein content of the feed. Seluolitik bacterial isolates have specific activity and have a commercial value in the processing of straw [14]. Based on the above that necessary to study development to improve the performance of fiber degrading bacteria in the feed by finding cellulolytic bacterial isolates using different media to obtain the bacteria can work optimally despite being outside of their natural environment.

\section{MATERIALS AND METHODS}

The sample was buffalo rumen fluid from cattle that have been accustomed to eating rice straw and slaughtered later taken rumen contents were still mixed with feed rough and perfect undigested. Sampling by squeezing buffalo rumen contents is then inserted into a flask which had been prepared approximately $500 \mathrm{ml}$ to be analyzed in the laboratory,

Isolation begins with rumen fluid dilution of the sample suspension made $10^{-2}$. by means of $1 \mathrm{ml}$ sample was diluted with $99 \mathrm{ml}$ of sterile distilled water into a separate tube. Suspension samples taken each $10^{-2}$ dilution $1 \mathrm{ml}$ of growth media were inoculated into 4 with 3 repetitions are Aerob Solid, Liquid Aerobic, Anaerobic Anaerobic Solid and liquid, solid media using substrates Carboxy Methyl cellulosa (CMC) agar nutrient (Merck KgaA) and liquid media use nutrient Browth (oxoid CM001).

Samples of anaerobic microbes in the liquid medium is placed on the test tube that had a vacuum and stored in a large tube joint anaerobic microbial samples on solid media were already vacuumed, then all media Bacterial samples were incubated for 48 hours at $37^{\circ} \mathrm{C}$. Isolates were grown on four media were taken and streaked onto Nutrient CMC media to use ose and plated on the Petri dish. Furthermore, inverted Petri dishes were incubated at $37^{\circ} \mathrm{C}$ for 48 hours [15]. For Petri dish, anaerobic isolates included in the tube that has been a vacuum. Colonies of bacteria were successfully grown on four media observed morphological forms.

Bacterial colonies morphological observation made in this study includes bacterial colony morphology character test includes shapes, edges and color [16] on Nutrient Agar media selected or CMC medium. The principle of insulation separating microbe is a microbe with other microbial species are derived from a mixture of various bacteria. This can be done with growing in dense media because of the dense microbial cells will form a colony of cells that remain in place [17]. Cellulolytic microbes with typical clear zone around the colony, colony color beige or off-white, opaque. The working principle cellulolitic bacterial rumen buffalo isolation based methods [9].

Qualitative test on bacterial colonies formed on the medium is measured using calipers and bacterial activity test conducted Congo Red staining method of $0.1 \%$ added to the media Nutrient Agar containing CMC as much as $15 \mathrm{ml}$ and allowed to stand for 30-60 minutes. Then wash 2-3 times with $15 \mathrm{~mL}$ of $1 \mathrm{M} \mathrm{NaCl}$ and allowed to stand for 15 minutes. Colonies of bacteria that produce a clear zone were purified with a scratchplate method [18-19]. Furthermore, the diameter of the clear zone is visible and formed around the colonies formed was measured using a caliper. According to [20] Congo Red will bind specifically to a polysaccharide having $\beta-1,4$ glycoside bondso that the clear zone formed around colonies clearly visible. Calculation cellulolitic index (CI) values by comparing the value of the diameter of the clear zone and the value of the diameter of the bacterial colony [15].The formation of a clear zone around the colonies of bacteria showed that the bacterial isolates mempu produce cellulase enzymes. Qualitatively, the amount of cellulase activity is expressed as an index of cellulolytic or cellulase activity index (IAS), obtained using the following formula [21]

$$
\text { Cellulolitic Indeks }=\frac{\text { Clear zone diameter }(\mathrm{mm})-\operatorname{colony} \text { diameter }(\mathrm{mm})}{\text { Colony diameter }(\mathrm{mm})}
$$

The data obtained in this study were related to the morphology was analyzed descriptively while data for the colony diameter, the diameter of clear zone, and cellulolytic indices were analyzed using a Completely Randomized Design (CRD) statistical software package SPSS.

\section{RESULT}

\section{The width of the colony diameter, Clear Zone diameter and cellulolytic Index}

Based on the analysis of variance and observation of macroscopic conducted laboratory by growing cellulolytic bacteria on four media are summarized in Table 1 diberoleh results in all four isolates were tested for their degradation, to produce cellulase qualitatively, indicating that the media treatment significantly $(\mathrm{P}<0,05)$ against the diameter of the colony and clear zone while 
the index measurement cellulolitic Table-1, in each treatment, showed that the average index cellulolitic to treatment with the isolates Anaerobic Solid highest average of $0.420 \mathrm{~mm}$ followed by three other isolates, namely the isolates Aerob Solid 0.35 $\mathrm{mm}$, Anaerobic Liquid $0.23 \mathrm{~mm}$ and Aerobic Liquid $0.13 \mathrm{~mm}$, in Statistik not significant $(\mathrm{P}>0.05)$.

Table 1: Average Average measurement results colony diameter, the diameter of the clear zone and the index cellulolitic four isolates of two growth media

\begin{tabular}{|c|c|c|c|}
\hline Type Isolates & The Colony Diameter $(\mathbf{m m})$ & Bening Zone Diameter $(\mathbf{m m})$ & Cellulolitic Index \\
\hline Solid aerobic & $18.783^{\mathrm{c}}$ & $24.975^{\mathrm{c}}$ & 0.35 \\
\hline Liquid aerobic & $13.283^{\mathrm{b}}$ & $14.833^{\mathrm{b}}$ & 0.13 \\
\hline Solid anaerobic & $12.567^{\mathrm{b}}$ & $17.283^{\mathrm{b}}$ & 0.42 \\
\hline Liquid anaerobic & $3.25^{\mathrm{a}}$ & $4.108^{\mathrm{a}}$ & 0.23 \\
\hline
\end{tabular}

Description $a, b$ and c: a different letter notation in the same column indicate significant differences $(P<0.05)$

\section{Bacterial isolates Morphological observation cellulolitic}

Based on observations of macroscopic colonies obtained by observing the edge shape and color of colonies of bacteria showed that there is a growth pattern that differs between isolates and usual bacteria from the rumen of buffalo has a shape of an irregular start small round, oval, oval serrated and forms such as roots, this showed that the bacteria obtained are quite varied.

Table 2: Form cellulolytic bacteria colony morphology on four isolates

\begin{tabular}{|c|c|c|c|}
\hline \multirow{2}{*}{ Name isolates } & \multicolumn{3}{|c|}{ Morphology of Colonies } \\
\cline { 2 - 4 } & Form & Edge & Color \\
\hline Solid aerobic & Oval round & flat & white \\
\hline Liquid aerobic & irregular & wavy (undulate) & yellow \\
\hline Solid anaerobic & Oval round & Jagged (erose) & white \\
\hline Liquid anaerobic & Small round & flat & white \\
\hline
\end{tabular}

Description: Irregular, undulate (wavy), erose

Picture 1. Presenting sightings isolate (Forms, edges and color of colonies) cellulolytic bacteria in 4 (four) growth media that has been poured $0.1 \%$ congo red is as follows:

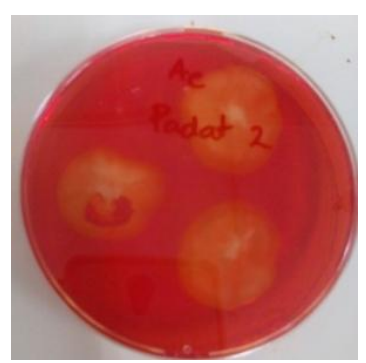

A

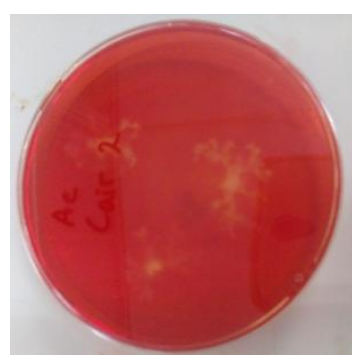

B

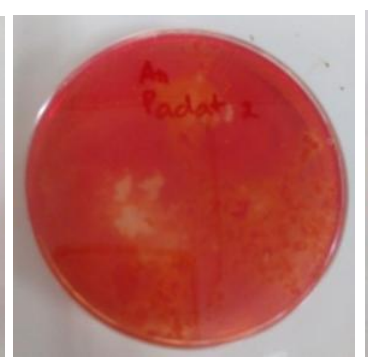

C

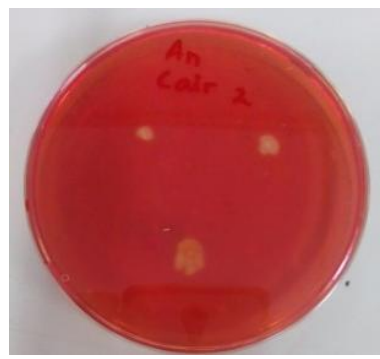

D

Figure 1: Zone lymph bacteria isolates grown on media: A. Solid aerobic, B. Liquid aerobic., C. Solid anaerobic, D.Liquid anaerobic.

\section{DISCUSSION}

The findings in this study revealed that the width of the diameter of the colony, the width of the diameter of clear zone and the index of cellulolytic and morphology isolates are presented in Table 1 outlines that cellulolytic bacteria were isolated on solid media and CMC CMC liquid that is characterized by a color change which becomes turbid media. Cellulolytic bacteria are heterotrophic bacteria that belonged to saprofit. Saprophyte bacteria are bacteria that can take advantage of the remains of plants that have died to meet the needs of the cell. This saprophyte bacteria need sugars (carbohydrates) in a certain amount of organic nitrogen, phosphorus and mineral salts as an energy source, amino acids, vitamins, sterols and so to meet the needs of the cell [22]. Cellulolytic bacterial growth at CMC media through certain phases. In the exponential phase occurs gain maximum cell. Based on the descriptive output in Table 1 obtained the average diameter of each colony isolates with Aerobic treatment mm Solid 18.7833, 13.2833 mm Liquid Aerobic, Anaerobic Anaerobic Solid and Liquid 12.5667 $3.2500 \mathrm{~mm} \mathrm{~mm}$

From the results of the analysis of variance obtained that there is a direct effect of the treatment of the colony diameter $(\mathrm{P}<0.05)$. It is seen from an $\mathrm{F}$ value of $20.801 \mathrm{~mm}$. After a further test showed that the treatment with bacteria Anaerobic Liquid (3.2500 $\mathrm{mm})$ was significantly different from other treatments, while between treatment Anaerobic Solid (12.5667 mm) and Aerob Liquid $(13.2883 \mathrm{~mm})$ there is no difference and treatment with Aerob Solid significantly different from treatment others. It further showed that the treatment with the highest growth in colony diameter is Aerob Solid (18.7833 mm). The difference in the width of colonies is caused by various factors according to [23]. That there are several factors that affect the magnitude of the 
diameter of colonies such as only colonies colonies spread that can be measured, because these colonies tend to have a larger diameter than those which are stacked. This is because competition in colonies spread less than the competition that occurs in colonies with reams and less challenged by substances byproducts.

To measure the ability of the isolates to degrade the substrate is determined by the width of the diameter of the clear zone formed on a medium containing CMC. The bacteria obtained showed positive qualities in cellulolytic ability test, so it can be suspected the four isolates were able to excrete cellulase enzymes capable of breaking $1.4 \beta$-glucoside bonds in the test medium. Cellulolytic capability can be seen from the growth of colonies on solid media CMC and CMC is able to grow on media. Cellulolytic bacterial growth in liquid CMC media can be seen from the color change becomes more turbid media. Cellulose degradation carried out with the aid of cellulase enzymes into glucose final result.

The formation of a clear zone indicates that the cellulose contained in the medium is hydrolyzed by cellulase enzymes into simple compounds that are cellobiose was then simplified into two molecules of glucose [24]. Pengukuran formed a clear zone around the colony is a semi-quantitative analysis of the activity of cellulolytic bacteria [25]. Colony isolates grown on CMC media that was 6 days with a solution of congo red drops of $0.1 \%$, to clarify the formation of the clear zone. Congo red has a strong interaction with bond chain polysaccharide containing $\beta$-(1.4) D-glukopiranosil [26].

Based on the results shown in Table 1 that wide clear zone produced per colony is different and this is because the hydrolysis of cellulose to glucose in solid medium CMC around the colonies visible part of the lighter around the colony, and the area is referred to as a light zone (Cleared zone), ability isolate the cellulose media proves that these isolates capable of utilizing cellulose as a source of nutrients. According to [27], cellulose can be used as a carbon and energy source for microbes. Each type of cellulolytic bacteria has its own ability to degrade cellulose. This study also showed that cellulolytic bacteria isolated from buffalo rumen fluid is able to grow on solid media and liquid media outside of their natural environment and can be saved as a fiber degrading isolates. As disclosed [28] that the buffalo rumen microbial isolates were stored in a long time (eight months) was still capable of positive synergy when combined with cow rumen microbes.

Results of variance analysis are summarized in Table- 1 shows that there is a direct effect of the treatment of the clear zone diameter $(\mathrm{P}<0.05)$ with an $\mathrm{F}$ value of $30.334 \mathrm{~mm}$. further test result that the treatment of anaerobic liquid $(4.108 \mathrm{~mm})$ was significantly different to other therapies, while Aerob Liquid (14.883 mm) and Anaerobic Solid (17.283 mm) there is no difference, and treatment Aerobic Solid significantly different with other treatments, this shows that the treatment with the highest diameter clear zone that is at Solid Aerobic isolates $(24.975 \mathrm{~mm})$. Differences wide clear zone depends on the solubility of the enzyme produced by bacteria, it is consistent with the statement [29] that formed a clear zone related to the solubility of the enzyme cellulase. The higher the solubility of the enzyme, the greater the clear zone is formed. The diameter of the clear zone is generally larger than the diameter of the colony, because of a cellulase enzyme is secreted into the surrounding environment by cellulose-degrading bacteria. The bacteria can not enter the cellulose molecules, because of the size of the cellulose is greater than the size of bacterial cells.

The polysaccharide will absorb congo red staining has ties $\alpha$-D- glukan. Terbentuknya clear zone indicates that saccharides with polysaccharides degraded into the shorter chain so it can not absorb the dye Congo Red [30]. In addition [29] revealed that formed a clear zone associated with the solubility of the enzyme cellulase. The higher the level of solubility of the enzyme, the greater the clear zone is created. The diameter of the clear area is generally larger than the diameter of the colony, because of a cellulase enzyme is secreted into the surrounding environment by cellulose-degrading bacteria is larger than the size of a bacterial cell.

This is according to a statement by [31-32] that the difference in index of each isolate cellulolitic because every species of bacteria have the ability to produce cellulase to hydrolyze a substrate different in CMC. Then added [33] that the potential cellulolitic can also be found in secreting cellulase enzymes by testing cellulolitic index seen by a clear zone around the colonies of bacteria that grow on the medium CMC. Some bacteria can produce cellulases that can degrade cellulose. Cellulase enzyme is an enzyme capable of degrading cellulose to break the ties $\beta-1,4$ glycoside, which produces cellulose derivatives and glucose oligosaccharides.

The presence of different isolates growth on an agar plate in this study (Figure 1) indicated that all the isolates were from different species of bacteria which form colonies by [34] can be used as the basis for the identification of bacteria. The observation in Table- 2 shows that in general, the color of colonies obtained in this study is white. The growth of bacteria on the media is determined by various factors such as disclosed [35] that, apart from microbial sources that determine the behavior of fiber digestion, is also determined by the microbial inoculum dose precisely, uniformity of species and populations of microbes used.

Different forms of colonies of each species and are characteristic for a specific species. The properties required in determining the identification of a species, for example, such as the size of the colony, shiny or not, smooth or rough surface and color of the colonies most bacteria have color whitish, gray, yellowish, or almost clear, but there are also species have clearer color pigments. The existence of color is affected by outside factors such as temperature, $\mathrm{pH}$, and oxygen-free. There are several species in need of phosphate; there is also a need sulphate to cause pigmentation [36]. At the edge of the shape of bacterial colonies obtained in this study, differences are ranging from a flat, wavy and jagged (Figure-1), this depends on several factors according to [23] that the edges of colonies of bacteria vary depending on the species. The form can be coiled flat like edge (side) of a droplet, or irregular like protrusions is curved, like a thread or as root.

In conclusion, based on research results found that the ability of cellulolytic bacteria grown on four growth media produces four types of colonies of bacteria isolates that have the capability of different fiber degradation and able to grow beyond its natural condition. Bacterial strains that showed the highest potential cellulolytic activity to degrade fiber-based index produced 
cellulolytic is on solid Aneraob isolate bacterial colonies. Isolates produced from bacterial colonies derived from the buffalo livestock in this study,

\section{ACKNOWLEDGMENT}

The authors are very grateful to the laboratory in an integrated laboratory Hasanuddin University Faculty of Animal Husbandry and buffalo farmers and workers in the Slaughterhouse in Makassar city Biringkanaya village who have helped during this research.

\section{REFERENCE}

[1] Nappu M B. 2013. Distribution Potential of Rice and Corn Waste Utilization well as in South Sulawesi, BPTP Sulawesi Selatan.Makassar.

[2] Natsir A. 2012. Fiber Utilization For ruminants, 1sted Masagenae Press, Makassar Indonesia

[3] Talib A, J Bestari, Y.Widiawati, H. Hamid, and D. Suherman. 2000. Effect of rice straw silage treatment with buffalo rumen microbial ecosystem of the digestibility and rumen of cattle. JITV 5 (1): 276-281.

[4] Djajanegara A. 1983. Overview Regarding Evaluation Birthday Supplement on Rice Straw. Proceedings of the Seminar on Food Waste Utilization and Waste Agriculture Animal Feed. Ed. AT. KAROCERI. LIPI, p. 192-197.

[5] Glass, DJ 1991. Waste Management: Biological treatment of Hazard o us Wastes. Enviroment. Heldreff Publication. New York.

[6] Saratale, G.D., Saratale, R.G, Oh, S.E 2012. Production and characterization Of Multiple Cellulolytic Isolated Enzymes By Streptomyces sp. MDS. Biomass and Bioenergy.47: 302 -315.

[7] Rifai, AA 2010. The role of cellulolytic bacteria isolates Facultative Origin Rumen Buffalo In contrast Forage. Essay. Faculty of Animal Husbandry. Bogor Agricultural Institute. Bogor.

[8] Budiana IN Dan NL G Budiari. 2014. The addition of cellulolytic rumen microbial cultures buffalo in rice straw to improve feed digestibility in vitro Proceedings of the national seminar on organic farming Bogor, 18 to 19 June, 2014

[9] Wahyudi and ZB Masduqie. 2004. Isolation of microbial cellulolytic rumen fluid some ruminants (buffalo, cow, goat, and sheep). Protein, Animal Husbandry and Fisheries Scientific Journal 11 (2): 181-186

[10] Prihantoro I, Toharmat T, Evyernie D, Syriac, and Abdullah L, 2012 The ability of fiber digesting bacteria rumen origin of buffalo on the various sources of forage. JITV. 17 (3): 189-200.

[11] Prabowo A, S Padmowijoyo, Bachruddin Z, and A Syulur. 2007. Potential cellulolytic mixture of extract termites, stool solution elephant, and buffalo rumen fluid. J of The Indonesian Tropical Anim. Agric. 32 (3): 151-158.

[12] Ismartoyo, 2011. Teaching materials for Ruminant Nutrition. Faculty of Animal Science. Hasanuddin University. Macassar.

[13] Jaelani A, WG Piliang, Suryahadi, and I Rahayu. 2008. Hydrolysis of palm kernel cake (Elaeis guineensis Jacq) by the fungus Trichoderma reesei mannan degrading polysaccharides. Animal Production Vol. 10 (1): 42-49.

[14] Singleton, I. S., and C. P. van Schaik. 2001. Orangutan Home range size and its determinants in a Sumatran swamp Forest. Int. J. Primatol. 22, 877-911

[15] Shajahan S., IG Moorthy, Sivakumar N., and G. Selvakumar. 2017. Statistical modeling and optimization of cellulose production by Bacillus licheniformis 5556 NCIM isolated from a hot spring, Maharashtra, India. Journal of King Saud University. 29: 302-310.

[16] Krairitthichai, S. and N. Thongwai. 2005. Isolation and Screening for cellulase Producing Bacteria. Science and Technology of Thailand, Thailand.

[17] Mulyani. 1991. Fundamentals of Soil Microbiology. Gramedia Pustaka Utama. Jakarta.

[18] Hadioetomo RS. 1993. Basic Microbiology in Practice. PT Gramedia Public Library. Jakarta.

[19] Ponnambalam, US, Deepthi, RS, and Ghosh, AR 2011. Qualitative display and measurement of enzymeactivityof isolated bacteria Cellulolytic research article, Biotechnol. Bioinf. Boeing.2011.1 (1): 33-37

[20] Anand, Vennison, Sankar, Prabhu, Vasan, Raghuraman, Geoffrey, and Vendan. 2009. Isolation and characterization of Bacteria from the Gut Of Bombyx Mori that Degrade Cellulose, Xylan, Pectin and Starch and Their Impact on Digestion. J of Insect Science. 10 (107): 1-20.

[21] Atlas, R.M.1981.Microbial Degradation of Petroleum Hydrocarbons: An Environmental Perspective.Microbiol.Rev.45: 180209

[22] Kader AJ dan Omar. O. 1998. Isolation of fungi from the wing Cellulolytic park kinabalu, sabah, serawak.j.biodeversity bio -conserv (ARBEC): 1 - 6

[23] Campbell, B. And E. Lack. 1985. A Dictionary of Birds. The British Ornithologist Union

[24] Tarigan. 1988.Morfologi bacterial colonies. Available from.https://www.academia.edu/ 25414187 / Microbiology Report .Morphology of Bacterial Colonies (Accessed, June 19, 2019)

[25] Perez J, Dorado JM, T de la Rubia, Martinez J. 2002. Biodegradation and biochemical treatments of cellulose, hemicellulose, and lignin: an overview.Int Microbiol 5: 53-63.

[26] Coughland MP, Mayer F. 1991. The cellulose decomposing bacteria and their enzyme systems. In the Balows A, Triper HG, Dworkin M, Harder W, Schleifer KH, editor. The Pro karyotes, A Handbook on the Biology of Bacteria: Ecophysiology, Isolation, Identification, Application. Vol I. New York: Springer Verlag. Pp 460 -516 
[27] Teather R.M, Wood P.J. 1982. Use of congo red polysacharide interactions in enumeration and characterization of bacteria from the bovine cellulolytics rumen.Appl Environ Microbiol 43: 777-780.

[28] Atlas, R.M.1981.Microbial Degradation of Petroleum Hydrocarbons: An Environmental Perspective.Microbiol.Rev.45: 180209

[29] Widiawati Y and M. Winugroho. 2009. Activities buffalo rumen microbial isolates were stored at low temperature. National Seminar and Workshop Papers, 2009. Buffalo Livestock Research Center, Ciawi, Bogor.

[30]Zverlova, VV, W.Holl, and H.Schwartz. 2003. Enzymes for digestion of cellulose and other polysaccharides in the gut of the longhorn beetle larvae, Rhagium Inquisitor L. (Col., Cerambiycidae). International Biodeterioration \& Biodegation, 51: $175-179$

[31]Zhang YHP, Himmel ME, \& Mielenz JR 2006. Outlok for cellulase environment: screening and selection strategies. Biotechnol Adv. 24: 452-481.

[32] Sudiana I.M, R.D. Rahayu, H. Imamuddin., and M. Rachmansyah. 2001. Celluloytic Bacteria of the Soil of the Mist Mountain National Park. Journal of Biology. 5 (6): 703-710.

[33] Sari, M., Agustien, U and Nurmiati, A. 2012. Screening and characterization of bacteria from river Cellulolytic thermophylic Medang hot Spring, Kerinci, Jambi. Biological Journal of Andalas. 1 (2): 166-171.

[34] Shovitri, M and D. Zahidah 2013.Isolasi, characterization and potential Aerobic bacteria as a degradation of organic waste. Journal of Science and Arts Pomits. 2 (1): 2337-3520.

[35] Volk and Wheeler. 1988. Basic Microbiology. Fifth edition. Volume I. publisher. Jakarta.

[36] Sudirman. 2011. Factors influencing the use of faecal buffalo instead of rumen fluid. Available from http://www.ugm.ac.id/ index.php? page $=$ release \& artikel645 (Accessed April 19, 2012)

[37] Dwidjoseputro.1987. Fundamentals of Microbiology. Publisher Djambatan. Jakarta 